\title{
Melatonin changes tularemia progression in a BALB/C mouse model
}

\author{
Miroslav Pohanka ${ }^{1 \star}$ and Oto Pavlis ${ }^{1,2}$ \\ ${ }^{1}$ Faculty of Military Health Sciences, University of Defense, Trebesska 1575, 50001 Hradec Kralove, Czech Republic. \\ ${ }^{2}$ Centre of Biological Defense, 56166 Techonin, Czech Republic.
}

Accepted 10 June, 2013

\begin{abstract}
Melatonin is a hormone with antioxidant properties. In the body, melatonin is involved in regulation of circadian biological rhythm. However, receptors for melatonin are expressed on disparate organs and they can be found on immune cells as well. The present experiment is focused on research whether melatonin would regulate pathogenesis caused by a model intracellular pathogen, Francisella tularensis. For this reason, laboratory mice BALB/c were chosen as a suitable model and they were infected with $F$. tularensis. Melatonin was given in two doses: 10 and $100 \mu \mathrm{g} / \mathrm{kg}$. Animals were sacrificed after either three or five days. Spleen and liver were sampled for bacterial burden. Interferon gamma (IFN-y), interleukin 2 (IL-2) and total immunoglobulins were assayed from plasma samples. The results showed administration of melatonin reduced bacterial burden in the organs in a dose response manner. Surprisingly, IFN-Y and IL-2 levels were reduced as well, while immunoglobulins remained unchanged. We conclude our experiment that melatonin is potent to reduce tularemia progression.
\end{abstract}

Key words: Melatonin, Francisella tularensis, tularemia, interferon gamma, interleukin 2, oxidative stress, pineal gland, inflammation.

\section{INTRODUCTION}

Melatonin (N-acetyl-5methoxytryptamine) is a compound created in the body from amino acid tryptophan (Natarajan et al., 2012). In the body of vertebrates, it comes from pineal gland and it is released to blood system in order to regulate circadian biological rhythms (Hasan et al., 2012). Namely, melatonin is involved in sleep regulation in both humans and animals (Hur et al., 2012). It also regulates seasonal body weight and sexual activities of some animals (Barrett and Bolborea, 2012) and vocal signatures in birds (Deregnaucourt et al., 2012). Action of melatonin is mediated through $G$ protein coupled melatonin receptors $\mathrm{MT}_{1}, \mathrm{MT}_{2}$, and $\mathrm{MT}_{3}$ expressed in disparate organs including brain, cardiovascular system, liver, intestine, kidney, and immune cells (Ekmekcioglu, 2006). Effect of melatonin is not well understood and it is believed that melatonin can modulate different pathological processes; however, it needs some more experiments to resolve the issue (Pohanka, 2011).

Melatonin was reported to be able to modulate immune system as stated by many researchers (Carrillo-Vico et al., 2013). Unfortunately, the findings are quite scarce and the results from the reported experiments are quite different in their conclusions. In an animal model, melatonin acting via $\mathrm{MT}_{1}$ was revealed to be responsible for release of interleuikin-2 (IL-2) and $\mathrm{MT}_{2}$ was excluded from the action (Ahmad et al., 2012). Cardinali et al. (2008) stated that melatonin stimulates production of natural killer cells and CD4+ cells and down regulates CD8+ cells. In another experiment, melatonin was shown to shift the balance between Th-1 and Th-2 lymphocytes to Th-1 (Srinivasan et al., 2008). On the other hand, another study indicated that melatonin can suppress immunity response previously stimulated with 
lipopolysaccharide (Ban et al., 2011). In the study, suppressive effect of melatonin was proved on macrophages. The cells had reduced expression of genes involved in regulation of immunity when compared to the controls. Wu et al. (2011) investigated effect of melatonin on microglia. They reported anti-inflammatory effect of melatonin and protection of hippocampus from Klebsiella pneumoniae induced pathology. Beside regulation of the immune response, melatonin can modulate immune system by inhibition of enzymes involved in killing of pathogens such as myeloperoxidase and NO synthase including the inducible isoform (Galijasevic et al., 2008; Koh, 2008). Beneficial effects of antioxidants including melatonin in infectious diseases are extensively researched and we can found opinions that melatonin is a promising compound suitable for a nonspecific therapy (Fares, 2013; Olegario et al., 2013; Poplawski et al., 2013).

In the present experiment, we focused our effort on research of possible immune response modulation by melatonin in tularemia infected mice. The disease is caused by Francisella tularensis, an intracellular pathogen being able to survive in and escape from macrophages (Mahawar et al., 2012). Both innate and adaptive immunity are necessary for resolving of tularemia. Beside innate immunity, interferon gamma (IFN- $\gamma$ ) is necessary for resolving of the disease and activation of the captured bacteria killing (Casbon et al., 2012). We chose a tularemia infected mice model for the test of melatonin effect. The primary intention of the experiment is to answer whether melatonin can improve or make worse the disease.

\section{MATERIALS AND METHODS}

\section{Bacterium}

Live vaccine strain of $F$. tularensis (American Type Culture Collection 29684) was used throughout. The vaccine strain is fully virulent for rodents (Conlan, 2011). The bacterium was cultivated on McLeod agar supplemented with bovine hemoglobin (SigmaAldrich, St. Louis, MO, USA) and IsoVitalexX (Becton-Dickinson, San Jose, CA, USA). The cultivation was carried out at $37^{\circ} \mathrm{C}$ for one day. After the cultivation, the cells were harvested using a disposable scraper, re-suspended in saline solution, and reharvested by centrifugation at $2,000 \times \mathrm{g}$ for $10 \mathrm{~min}$. Finally, the cells were re-suspended in saline in order to be used in the in vivo experiments. Concentration of the cells in the suspension was estimated by calibrated turbidimetric assay and exact concentration $2.77 \times 10^{6} \mathrm{CFU} / \mathrm{ml}$ of viable cells in the suspension was confirmed by cultivation test one day later.

\section{Laboratory animals}

Laboratory female mice BALB/c (Velaz, Unetice, Czech Republic) were chosen for the experiment purposes. The mice are an accepted model for tularemia and results from the experiment can be easily extrapolated to previous findings (Shen et al., 2010). In the experiment beginning, the mice weighed $21 \pm 1 \mathrm{~g}$ at eight weeks old. The animals were kept in an air conditioned room with tempe- rature $22 \pm 2^{\circ} \mathrm{C}$ and humidity $50 \pm 10 \%$. In the room, lighting lasted 12 $\mathrm{h}$ per day. The animals had free access to food and water. The experiment was approved and supervised by the ethical committee at Centre of Biological Defense in Techonin (Czech Republic).

The animals were divided into eight groups of 12 specimens. For the experimental purposes, melatonin in analytical purity was obtained from Sigma-Aldrich and solved in saline with $10 \%(\mathrm{v} / \mathrm{v})$ ethanol. Animals in the individual groups received subcutaneous (neck skinfold) application of solutions in compliance with the following overview:

First group received $50 \mu \mathrm{l}$ of saline with $10 \%(\mathrm{v} / \mathrm{v})$ of ethanol first and second day of the experiment. The animals in the first group were sacrificed after five days.

Second group received $50 \mu \mathrm{l}$ of melatonin solution providing dose $100 \mu \mathrm{g} / \mathrm{kg}$. Melatonin was resolved in saline with $10 \%(\mathrm{v} / \mathrm{v})$ ethanol. The doses were given the first and the same dose the second day after experiment beginning. The animals were sacrificed after five days.

Third group received $100 \mu \mathrm{l}$ of $F$. tularensis suspension and $50 \mu \mathrm{l}$ of saline with $10 \%(\mathrm{v} / \mathrm{v})$ of ethanol one hour later. The application of saline with ethanol was repeated the second day. The animals were sacrificed after three days.

Fourth group received $100 \mu \mathrm{l}$ of $F$. tularensis suspension and $50 \mu \mathrm{l}$ of melatonin solution providing dose $10 \mu \mathrm{g} / \mathrm{kg}$. Melatonin was solved in saline with $10 \%(\mathrm{v} / \mathrm{v})$. Melatonin was applied one hour after the $F$. tularensis and then again after one day. The animals were sacrificed after three days.

Fifth group received $100 \mu \mathrm{l}$ of $F$. tularensis suspension and $50 \mu \mathrm{l}$ of melatonin solution providing dose $100 \mu \mathrm{g} / \mathrm{kg}$. Melatonin was solved in saline with $10 \%(\mathrm{v} / \mathrm{v})$. Melatonin was applied one hour after the $F$. tularensis and then again after one day. The animals were sacrificed after three days.

Sixth group received $100 \mu \mathrm{l}$ of $F$. tularensis suspension and $50 \mu \mathrm{l}$ of saline with $10 \%(\mathrm{v} / \mathrm{v})$ of ethanol one hour later. The application of saline with ethanol was repeated the second day. The animals were sacrificed after five days.

Seventh group received $100 \mu \mathrm{l}$ of $F$. tularensis suspension and 50 $\mu \mathrm{l}$ of melatonin solution providing dose $10 \mu \mathrm{g} / \mathrm{kg}$. Melatonin was solved in saline with $10 \%(\mathrm{v} / \mathrm{v})$. Melatonin was applied one hour after the $F$. tularensis and then again after one day. The animals were sacrificed after five days.

Eight group received $100 \mu \mathrm{l}$ of $F$. tularensis suspension and $50 \mu \mathrm{l}$ of melatonin solution providing dose $100 \mu \mathrm{g} / \mathrm{kg}$. Melatonin was solved in saline with $10 \%(\mathrm{v} / \mathrm{v})$. Melatonin was applied one hour after the $F$. tularensis and then again after one day. The animals were sacrificed after five days.

The sacrifice was performed by $\mathrm{CO}_{2}$ anesthesia. Blood was collected from hearth into tubes with lithium heparin (Dialab, Prague, Czech Republic). The freshly collected blood was centrifuged at $1,000 \times \mathrm{g}$ for $5 \mathrm{~min}$ and plasma was separated. The plasma samples were kept at $-80^{\circ} \mathrm{C}$ until ex vivo assay. Spleen and liver were sampled from the cadavers as well. The organs were used for bacterial burden assay immediately after the collection.

\section{Assay of selected markers}

IL-6 and IFN-y were assayed using a commercial enzyme linked immuno sorbent assay (ELISA) kit from Abcam (Cambridge, MA, USA). The kits were processed in compliance with instructions using polystyrene 96-well microplates (Gama, Ceske Budejovice, Czech Republic) and a microplate reader Sunrise (Tecan, Salzburg, Austria). Total immunoglobulins were assayed by a direct ELISA using the aforementioned microplates and device. $20 \mu \mathrm{l} /$ well of the serum sample and $180 \mu \mathrm{l} /$ well of phosphate buffered saline were mixed and incubated at $37^{\circ} \mathrm{C}$ overnight. The wells were washed by 
phosphate buffered saline and free surface was blocked by $100 \mu \mathrm{l}$ of $0.1 \%(\mathrm{w} / \mathrm{v})$ gelatin at $37^{\circ} \mathrm{C}$ for $1 \mathrm{~h} .100 \mu \mathrm{l}$ of anti-mouse immunoglobulin (specificity to $\mathrm{G}, \mathrm{A}$, and $\mathrm{M}$ isotypes) polyclonal antibody labeled with horseradish peroxidase (Sigma-Aldrich) diluted 1:1000 were injected per well and incubated at $37^{\circ} \mathrm{C}$ for $1 \mathrm{~h}$. After that, the microplate was washed with phosphate buffered saline with addition of Tween 20 (Sigma-Aldrich). Fresh solution of $0.5 \mathrm{mg} / \mathrm{ml} \quad$ phenylenediamine and $5 \mathrm{mmol} / / \mathrm{H}_{2} \mathrm{O}_{2}$ was added for 1 min and reaction was stopped with $100 \mu \mathrm{l} /$ well of $2 \mathrm{~mol} / \mathrm{l} \mathrm{H}_{2} \mathrm{SO}_{4}$. Optical density was measured at $490 \mathrm{~nm}$. Wells with captured albumin (20 $\mu \mathrm{l} ; 5 \mathrm{mg} / \mu \mathrm{l})$ were used for negative control purposes. Standard immunoglobulin from mouse was used for calibration purposes.

The organ samples (spleen and liver) were mechanically homogenized immediately after collection. They were passed through nylon net with holes sized $1 \mathrm{~mm}^{2}$. The fresh homogenate was re-suspended into saline and injected over the McLeod Agar with composition and cultivation conditions as mentioned above.

\section{Statistical analysis}

The achieved data were processed in Origin 8 Pro (OriginLab Corporation, Northampton, MA, USA) software using one-way ANOVA test with Scheffe test. The both probability levels $P<0.05$ and $\mathrm{P}<0.01$ were calculated.

\section{RESULTS}

The first two $\left(1^{\text {st }}\right.$ and $\left.2^{\text {nd }}\right)$ groups treated with saline or melatonin only had no clinical manifestation. The last six groups of animals $\left(3^{\text {rd }}-8^{\text {th }}\right)$ were infected with $F$. tularensis. No difference in clinical manifestation was observed for groups $3^{\text {rd }}-8^{\text {th }}$. The applied dose of $F$. tularensis was sub-lethal so no demission occurred during the experiment. Full manifestation of the symptoms was seen three days after tularemia starting and remained up to the end of the experiment.

Bacterial burden is depicted in Figure 1 for liver and Figure 2 for spleen. The organs were chosen because they are typically invaded by $F$. tularensis (Ellis et al., 2002; Sharma et al., 2011). In the liver, melatonin caused dose dependent decrease of bacterial burden in the both time intervals 3 and 5 days after the experiment beginning. The decrease was significant on probability level 0.01. Effect of melatonin on bacterial presence in the spleen was milder when compared to the liver. The decrease in the spleen was significant (probability level $0.05)$ three days after the experiment beginning. Five days after the experiment beginning, dose dependent but not significant decrease in the spleen was seen.

Assay of antibodies provided no significant effect of melatonin on immune response (data not shown). Average content of total $\lg \mathrm{g}, \lg A$ and $\lg M$ was $8.3 \pm 2.5$ $\mathrm{mg} / \mathrm{ml}$. Melatonin alone did not cause change in the antibodies. Tularemia caused alteration in antibodies level around $20 \%$. However, this alteration was insignificant. Plasmatic level of IL-6 is depicted in Figures 3 and 4. All infected animals had significantly $(P<0.01)$ increased IL- 6 when compared to the first two groups (controls and the exposed to melatonin). Melatonin alone had no effect on secretion of IL-6. In the tularemia infec- ted animals, melatonin caused decline of IL-6 level three days after the infection started. The upper dose of melatonin provided significant $(P<0.05)$ decrease of IL-6 three days after infection started. Effect of melatonin on IL-6 was in a dose dependent manner in the interval three days. However, melatonin had no plausible effect five days after infection started. When compared to the two intervals, it is obvious that inflammatory immune reaction damp out after the longer time.

IFN- $\gamma$ is the last marker described here. It is a cytokine necessary for resolving of a disease caused by an intracellular pathogen. In the $F$. tularensis invaded macrophages, it can interfere replication of the pathogen and thus suppress progression of the disease (Zhou et al., 2012). In the experiment reported here, we proved significant $(P<0.01)$ increase of IFN- $y$ in the tularemia infected animals incorporated into the $3^{\text {rd }}$ group, and in the infected animals in the $6^{\text {th }}-8^{\text {th }}$ groups. Melatonin had no effect on IFN- $y$ five days after experiment beginning. However, tularemia infected animals which received melatonin had IFN- $\gamma$ level not significant to controls. Three days after experiment beginning, the upper dose of melatonin caused significant $(P<0.05)$ decrease in IFN- $y$ level when compared to the infected animals that did not received melatonin.

\section{DISCUSSION}

The infected animals had typical symptoms of tularemia such as lethargy, and ruffled fur, as has been reported in previous studies (Hepburn and Simpson, 2008; Nigrovic and Wingerter, 2008). Owing to the bacterial burden, the effect cannot be attributed to pertinent melatonin cytotoxic effect on the pathogen as the compound is harmless and there is no evidence that melatonin would kill either host or pathogen cells (Ono et al., 2012; Uguz et al., 2012; Wang et al., 2012).

The level of antibodies corresponded to assumptions from experiments on humoral immunity in tularemia suffered animals (Koskela and Salminem 1985). When effect of melatonin on antibodies production is searched, ambiguous data can be found. Both decrease (Zhoul et al., 2010) and increase (Regodon et al., 2009) in course of melatonin can be found in plasma after challenge by an antigen. The findings about antibodies reported here neither confirm nor neglect the mentioned experiments.

Intervention of melatonin in innate immunity is not surprising as attenuation of IL- 6 secretion in course of melatonin was described by other researchers as well (Laliena et al., 2012; Lau et al., 2012; Wu et al., 2012). Effect of melatonin on inflammation is not probably privileged to IL-6 only as anti-inflammatory effect of melatonin on other inflammatory cytokines is reported in current literature (Wu et al., 2012). The effect is probably mediated via nuclear factor-kappa $B$ and nuclear erythroid 2-related factor 2 (Negi et al., 2011). When searched literature, desperate knowledge about melatonin 


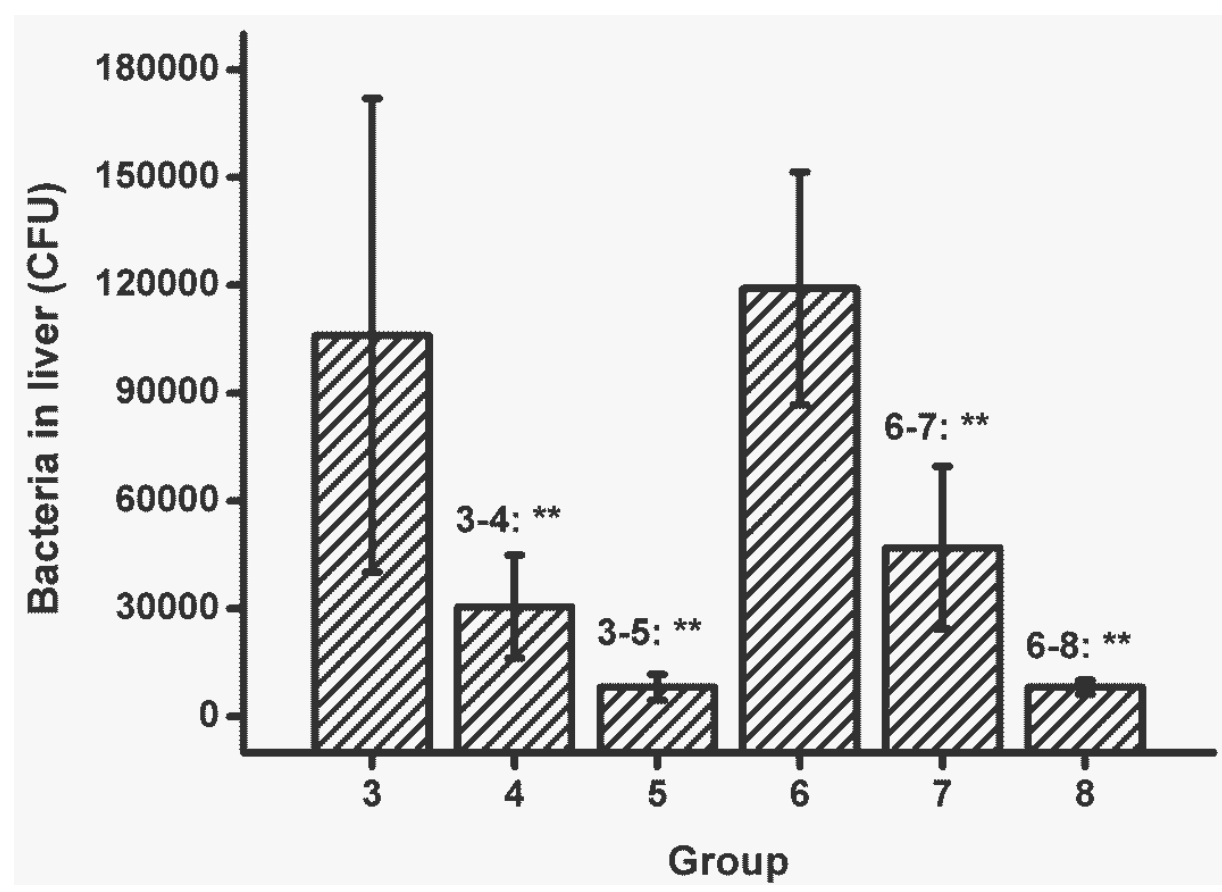

Figure 1. F. tularensis LVS viable cells in the livers of mice BALB/c. Significance between the groups was tested for two probability levels $\mathrm{P}<0.05\left(^{*}\right)$ and $\mathrm{P}<0.01\left(^{* *}\right)$.

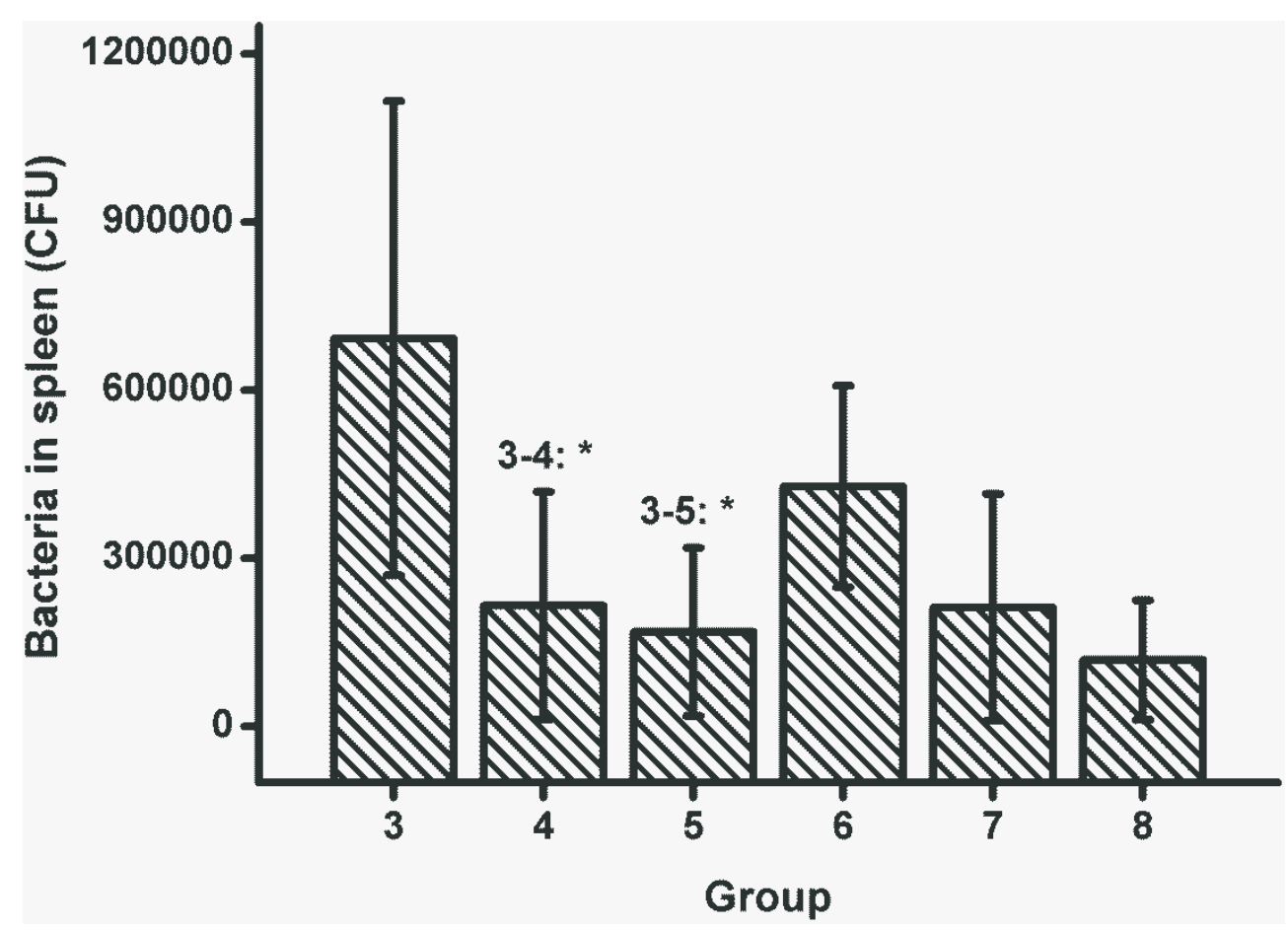

Figure 2. $F$. tularensis LVS viable cells in the spleens of mice BALB/c. Significance between the groups was tested for two probability levels $\mathrm{P}<0.05\left(^{*}\right)$ and $\mathrm{P}<0.01\left(^{* *}\right)$.

effect on IFN-y level can be learned. While Oliveira et al. (2010) reported release of IFN- $y$ in course of melatonin in a Wistar rat model, Kim et al. (2012) revealed suppres- sion of IFN-y in a mice model three days after melatonin application (Kim et al., 2012).

The findings reported here are quite surprising as the 


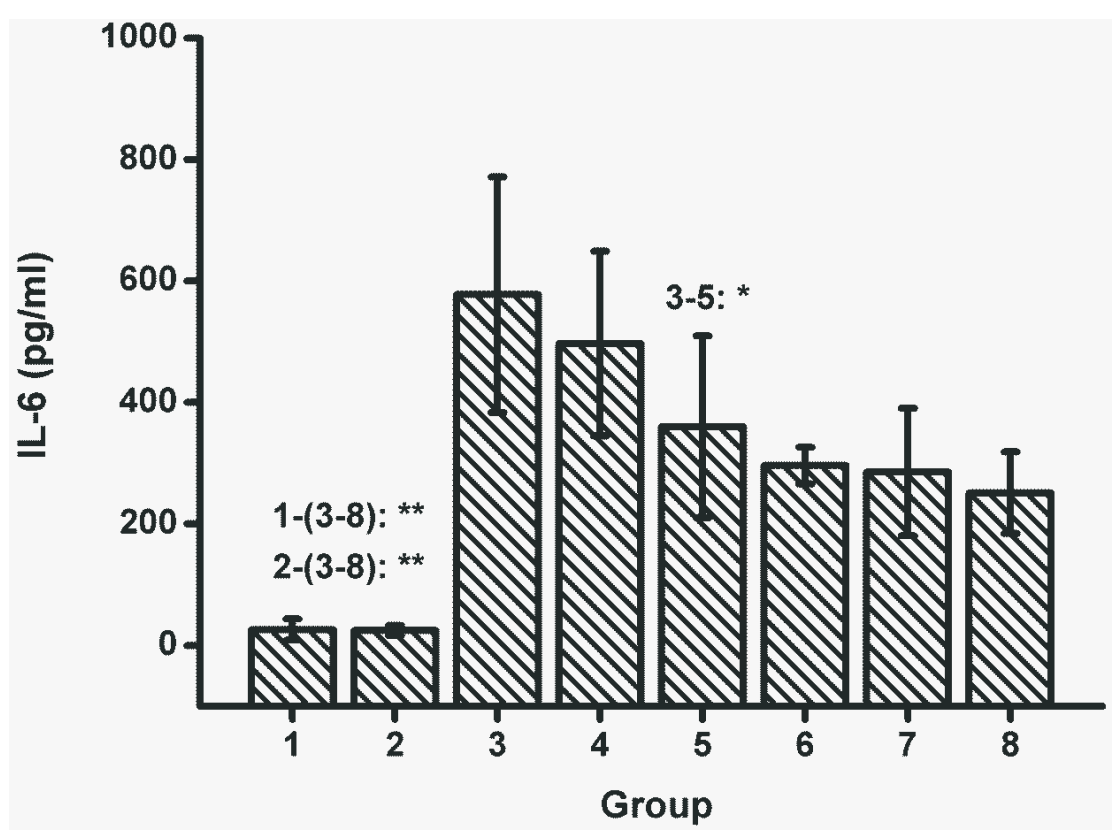

Figure 3. IL-6 level in plasma. Significance between the groups was tested for two probability levels $\mathrm{P}<0.05\left(^{*}\right)$ and $\mathrm{P}<0.01\left(^{* *}\right)$.

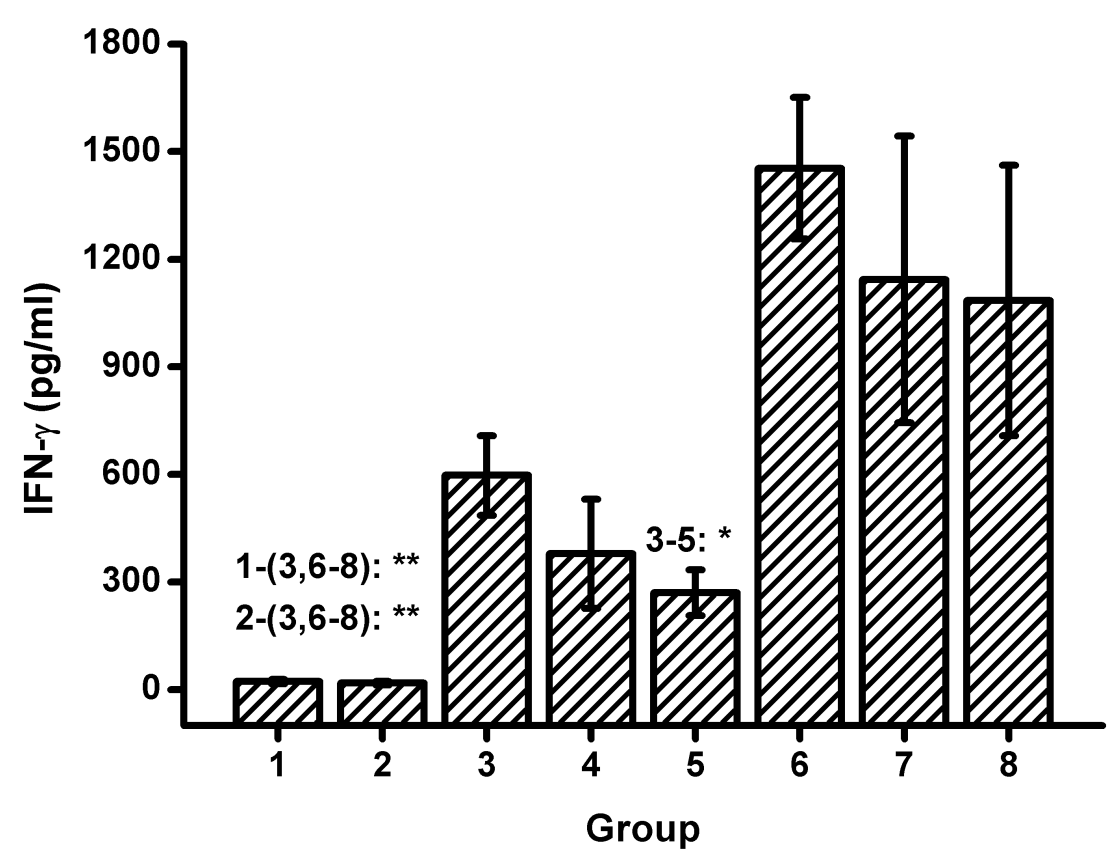

Figure 4. IFN-y level in plasma. Significance between the groups was tested for two probability levels $\mathrm{P}<0.05\left(^{*}\right)$ and $\mathrm{P}<0.01\left(^{* *}\right)$.

both IFN- $\gamma$, IL-6 and bacterial burden were reduced. It means that melatonin can reduce bacterial burden despite suppression of immunity. It is not easy to answer the described phenomenon. The cytokines could be decreased due to reduction of number of invading bacteria. However, we are not able to recognize what cause and consequence is. We can infer that the mela- tonin effect could lay in another mechanism than immunity control. Some possible mechanisms can be revealed from literature. Melatonin can change level of intracellular calcium and cAMP. It regulates kinase activity and cell cycle in this way (Bagnaresi et al., 2012). Melatonin is also able to initiate expression of extracellular mitogen-activated protein kinase, ERK, and 
signal transducer and activator of transcription STAT 3 (Laliena et al., 2012). As a result of the melatonin action, alteration in apoptosis and basal metabolism can be expected (Boga et al., 2012; Pohanka, 2011). It is a question whether melatonin reduces bacterial burden and the here assessed markers IL-6 and IFN- $\gamma$ are decreased consequently or two independent pathways can be recognized in the body. Aforementioned necessity of IFN$Y$ for tularemia resolving neglect the idea that melatonin would intermediate its beneficial effect on the disease this way. However, more specific experiment on the melatonin effect on the bacteria should be done prior to give the final answer.

\section{Conclusions}

Melatonin is able to modulate tularemia disease. We assume that it acts through cell cycle regulation rather than direct effect on cytokines release. Though evidence of the pathways is not clear enough to provide simple conclusion, melatonin appears to be a perspective compound for pharmacological research on infectious disease treatment. We can conclude our experiment by statement that melatonin would ameliorate progression of tularemia probably by restriction of $F$. tularensis growth. However, research is needed to get more detailed knowledge about melatonin action.

\section{ACKNOWLEDGEMENT}

A long-term organization development plan 1011 (Faculty of Military Health Sciences, University of Defense, Czech Republic) is gratefully acknowledged.

\section{REFERENCES}

Ahmad R, Haldar C, Gupta S (2012). Melatonin membrane receptor type MT1 modulates cell-mediated immunity in the seasonally breeding tropical rodent Funambulus pennanti. Neuroimmunomodulation 19:50-59.

Bagnaresi P, Nakabashi M, Thomas AP, Reiter RJ, Garcia CRS (2012). The role of melatonin in parasite biology. Mol. Biochem. Parasitol. 181:1-6.

Ban JY, Kim BS, Kim SC, Kim DH, Chung JH (2011). Microarray Analysis of Gene Expression Profiles in Response to Treatment with Melatonin in Lipopolysaccharide Activated RAW 264.7 Cells. Korean J. Physiol. Pharmacol. 15:23-29.

Barrett $P$, Bolborea M (2012). Molecular pathways involved in seasonal body weight and reproductive responses governed by melatonin. J. Pineal Res. 52:376-388.

Boga JA, Coto-Montes A, Rosales-Corral SA, Tan DX, Reiter RJ (2012). Beneficial actions of melatonin in the management of viral infections: a new use for this "molecular handyman"? Rev. Med. Virol. 22:323-338.

Cardinali DP, Esquifino AI, Srinivasan V, Pandi-Perumal SR (2008). Melatonin and the immune system in aging. Neuroimmunomodulation 15:272-278.

Carrillo-Vico A, Lardone PJ, Alvarez-Sanchez N, Rodriguez-Rodriguez A, Guerrero JM (2013). Melatonin: buffering the immune system. Int. J. Mol. Sci. 14:8638-8683.
Casbon AJ, Long ME, Dunn KW, Allen LAH, Dinauer MC (2012). Effects of IFN-gamma on intracellular trafficking and activity of macrophage NADPH oxidase flavocytochrome b(558). J. Leukoc. Biol. 92:869-882.

Conlan JW (2011). Tularemia vaccines: recent developments and remaining hurdles. Future Microbiol. 6:391-405.

Deregnaucourt S, Saar S, Gahr M (2012). Melatonin affects the temporal pattern of vocal signatures in birds. J. Pineal Res. 53:245258.

Ekmekcioglu C (2006). Melatonin receptors in humans: biological role and clinical relevance. Biomed. Pharmacother. 60:97-108.

Ellis J, Oyston PCF, Green M, Titball RW (2002). Tularemia. Clin. Microbiol. Rev. 15:631-646.

Fares A (2013). Factors influencing the seasonal patterns of infectious diseases. Int. J. Prev. Med. 4:128-132.

Galijasevic S, Abdulhamid I, Abu-Soud HM (2008). Melatonin is a potent inhibitor for myeloperoxidase. Biochemistry 47:2668-2677.

Hasan S, Santhi N, Lazar AS, Slak A, Lo JN, von Schantz M, Archer SN, Johnston JD, Dijk DJ (2012). Assessment of circadian rhythms in humans: comparison of real-time fibroblast reporter imaging with plasma melatonin. Faseb J. 26:2414-2423.

Hepburn MJ, Simpson AJH (2008). Tularemia: current diagnosis and treatment options. Expert Rev. Anti-Infect. Ther. 6:231-240.

Hur SP, Takeuchi Y, Itoh H, Uchimura M, Takahashi K, Kang HC, Lee YD, Kim SJ, Takemura A (2012). Fish sleeping under sandy bottom: Interplay of melatonin and clock genes. Gen. Comp. Endocrinol. 177:37-45.

Kim JY, Lee YD, Kim BJ, Kim SP, Kim DH, Jo KJ, Lee SK, Lee KH, Baik HW (2012). Melatonin improves inflammatory cytokine profiles in lung inflammation associated with sleep deprivation. Mol. Med. Rep. $5: 1281-1284$.

Koh PO (2008). Melatonin regulates nitric oxide synthase expression in ischemic brain injury. J. Vet. Med. Sci. 70: 747-750.

Koskela P, Salminem A (1985). Humoral immunity against Francisella tularensis after natural infection. J. Clin. Microbiol. 22:973-979.

Laliena A, San Miguel B, Crespo I, Alvarez M, Gonzalez-Gallego J, Tunon MJ (2012). Melatonin attenuates inflammation and promotes regeneration in rabbits with fulminant hepatitis of viral origin. J. Pineal Res. 53:270-278.

Lau WWI, Ng JKY, Lee MMK, Chan ASL, Wong YH (2012). Interleukin6 autocrine signaling mediates melatonin MT1/2 receptor-induced STAT3 Tyr705 phosphorylation. J. Pineal Res. 52:477-489.

Mahawar M, Atianand MK, Dotson RJ, Mora V, Rabadi SM, Metzger DW, Huntley JF, Harton JA, Malik M, Bakshi CS (2012). Identification of a novel Francisella tularensis factor required for Intramacrophage survival and subversion of innate immune response. J. Biol. Chem. 287:25216-25229.

Natarajan R, Einarsdottir E, Riutta A, Hagman S, Raunio M, Mononen N, Lehtimaki T, Elovaara I (2012). Melatonin pathway genes are associated with progressive subtypes and disability status in multiple sclerosis among Finnish patients. J. Neuroimmunol. 250:106-110.

Negi G, Kumar A, Sharma SS (2011). Melatonin modulates neuroinflammation and oxidative stress in experimental diabetic neuropathy: effects on NF-kappa B and Nrf2 cascades. J. Pineal Res. 50:124-131.

Nigrovic LE, Wingerter SL (2008). Tularemia. Infect. Dis. Clin. North Am. 22:489-504.

Olegario JG, Silva MV, Machado JR, Rocha LP, Reis MS, Guimaraes CS, Correa RR (2013). Pulmonary innate immune response and melatonin receptors in the perinatal stress. Clin. Dev. Immunol. 2013:340959.

Oliveira LGR, Kuehn CC, Santos CD, Toldo MPA, do Prado JC (2010). Enhanced protection by melatonin and meloxicam combination in experimental infection by Trypanosoma cruzi. Parasite Immunol. 32:245-251.

Ono K, Mochizuki H, Ikeda T, Nihira T, Takasaki J, Teplow DB, Yamada $M$ (2012). Effect of melatonin on alpha-synuclein self-assembly and cytotoxicity. Neurobiol Aging 33:2172-2185

Poplawski T, Chojnacki C, Czubatka A, Klupinska G, Chojnacki J, Blasiak J (2013). Helicobacter pylori infection and antioxidants can modulate the genotoxic effects of heterocyclic amines in gastric mucosa cells. Mol. Biol. Rep. In press. 
Pohanka M (2011). Alzheimer's disease and related neurodegenerative disorders: implication and counteracting of melatonin. J. Appl. Biomed. 9:185-196.

Regodon S, Ramos A, Morgado S, Tarazona R, Martin-Palomino P, Rosado JA, Miguez Midel P (2009). Melatonin enhances the immune response to vaccination against $A 1$ and $C$ strains of Dichelobacter nodosus. Vaccine 27:1566-1570.

Sharma J, Mares CA, Li Q, Morris EG, Teale JM (2011). Features of sepsis caused by pulmonary infection with Francisella tularensis Type A strain. Microb. Pathog. 51:39-47.

Shen H, Harris G, Chen WX, Sjostedt A, Ryden P, Conlan W (2010). Molecular Immune Responses to Aerosol Challenge with Francisella tularensis in Mice Inoculated with Live Vaccine Candidates of Varying Efficacy. PLoS One 5(10): e13349.

Srinivasan V, Spence DW, Trakht I, Pandi-Perumal SR, Cardinali DP, Maestroni GJ (2008). Immunomodulation by melatonin: Its significance for seasonally occurring diseases. Neuroimmunomodulation 15:93-101.

Uguz AC, Cig B, Espino J, Bejarano I, Naziroglu M, Rodriguez AB, Pariente JA (2012). Melatonin potentiates chemotherapy-induced cytotoxicity and apoptosis in rat pancreatic tumor cells. J. Pineal Res. 53:91-98.

Wang Z, Liu DX, Wang JT, Liu SM, Gao M, Ling EA, Hao AJ (2012). Cytoprotective effects of melatonin on astroglial cells subjected to palmitic acid treatment in vitro. J. Pineal Res. 52:253-264.
Wu UI, Mai FD, Sheu JN, Chen LY, Liu YT, Huang HC, Chang HM (2011). Melatonin inhibits microglial activation, reduces proinflammatory cytokine levels, and rescues hippocampal neurons of adult rats with acute Klebsiella pneumoniae meningitis. J. Pineal Res. 50:159-170.

Wu WS, Chou MT, Chao CM, Chang CK, Lin MT, Chang CP (2012). Melatonin reduces acute lung inflammation, edema, and hemorrhage in heatstroke rats. Acta Pharmacol. Sin. 33:775-782.

Zhou HW, DeLoid G, Browning E, Gregory DJ, Tan FX, Bedugnis AS, Imrich A, Koziel H, Kramnik I, Lu Q, Kobzik L (2012). Genome-Wide RNAi Screen in IFN-gamma-Treated Human Macrophages Identifies Genes Mediating Resistance to the Intracellular Pathogen Francisella tularensis. PLoS One 7(2):e31752.

Zhoul LL, Wei W, Si JF, Yuan DP (2010). Regulatory effect of melatonin on cytokine disturbances in the pristane-induced lupus mice. Mediators Inflamm. 2010:ID951210. 